\title{
Design of solar photovoltaic pressurized drip irrigation pumping system at Al-salman District in Samawa Governorate
}

\author{
Raghad Ali Mejeed, Samah Shyaa Oudah, Rasha Yasen Abed \\ Department of Electrical and Machine Department, College of Engineering Diyala, Iraq
}

\begin{tabular}{l}
\hline \hline Article Info \\
\hline Article history: \\
Received Dec 12, 2018 \\
Revised Mar 2, 2019 \\
Accepted Apr 3, 2019 \\
\hline
\end{tabular}

Keywords:

Cropwat8

Drip irrigation

IRRIPRO Software

Pumping system

Solar radiation

Uniformity coefficient

Water requirements

\begin{abstract}
The seasonal climate changes have direct effects on determination of crop water requirement, irrigation scheduling and the potential of solar energy generation to operate the pumping system for watering crops. This research paper studied the technical evaluation of solar pumping and pressurized drip irrigation systems to investigate the recommended water required for suggested tomatoes crop in area of (one hectare) at AL-Salman district using measured climatic data from AL-Salman Agro-meteorological weather station for a period (2013-2017). The maximum average monthly of solar radiation was $7.6 \mathrm{kWh} / \mathrm{m} 2$ at June in all the years of recording data, while the minimum average monthly value was $3.37 \mathrm{kWh} / \mathrm{m} 2$ at December where the sun at lowest point across the sky. The annual average hours of peak sun that corresponds to the operation time of the pumping system at maximum water consumption was calculated at eight months from March to October with a value of 7.2 hours/day, while it was 5.2 hours/day during the other four months (January, February, November and December). The Solar pumping sizing based on H-Q performance curve of a maximum flow rate of 64.45 $\mathrm{m} 3 / \mathrm{h}$ and pump capacity of $16.79 \mathrm{~kW}$ with compounds motor pump efficiency of $61.2 \%$. The total water production was $230000 \mathrm{~m}^{3} /$ per year which indicates compatible overall system design and adequate to irrigate more planting land with same or other crop types.
\end{abstract}

Copyright (c) 2019 Institute of Advanced Engineering and Science. All rights reserved.

\section{Corresponding Author:}

Raghad Ali Mejeed,

Departement of Electrical and Machine Department,

Diyala University, Diyala Governorate, Iraq.

Email: dr.raghadaljourni@gmail.com

\section{INTRODUCTION}

The global warming and climate change are the biggest problem of using fossil fules. Therefore, it important to use an alternative source of energy to achieve cleaner environment with low cost of manufacturing. The sector of electricity in Iraq has been endured from many problems since 1990 up to now. Fossil fuel and the decreasing in water of Tigris and Euphrates led many researchers to find alternative way to generat electricity and agriculture irrigation and therefore, renewable energy such as solar, wind, bio mass and geothermal energies are one of these ways, which necessary to be used to generate electricity for different potential uses [1-3]. Moreover, the increase in the population has been made the water availibilt very significant. Therefore, the effective management of water resources in agriculture irrigation is crucial role to sustain the future of food security. Generally, there are two types according to the source of feeding electricity to irrigate farm especially in rural area. The first type is the conventional pumping systems which can be fed by grid electrical system or working on diesel fuel. While, the second type is the isolated pumping systems, which work on available solar power, without electrical storage [4]. The later type is one of the most effective and effecinet way to irrigate the farm which is called drip irrigation way [5]. This way is widely used in agriculture irrigation with the help of solar energy (photovoltaic) especially in drip irrigation pumping system $[6,7]$. 
PV "photovoltaic" solar energy has been widley used to generate electricity to operate the pumping system, especially in the location where there is a limited or no other sources of energy. This has vital benefit such that there is no diesel pump repair required and any type of fule will be useless [8]. Figure 1 clearly shows how the PV panel can be used as a solar drip irrigation system. The figure clearly showed that several factors may affect the design of the system unit.

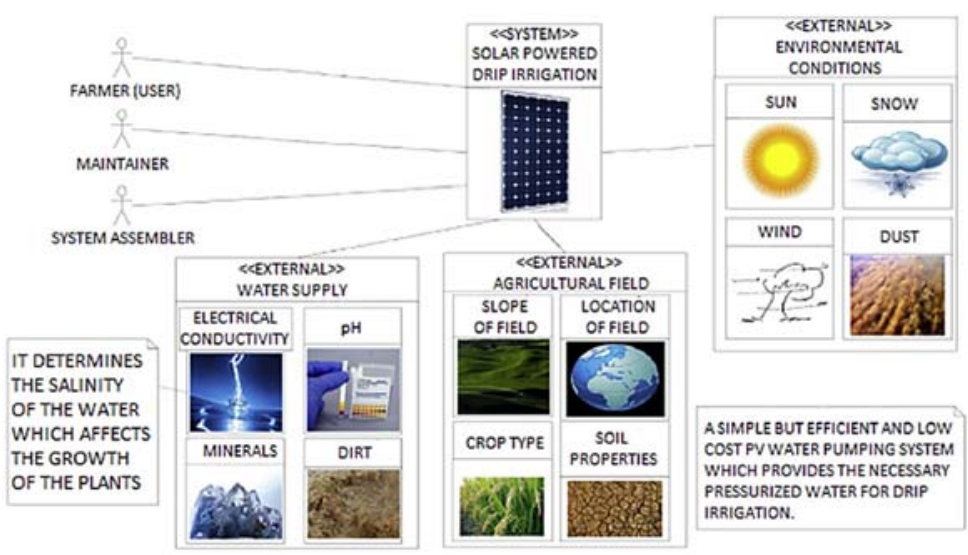

Figure 1. Digram showing the solar drip irrigation system [9]

Two studied sites in Sangasar and Karkuk of Iraqi Kurdistan were studied using "CROPWAT 8.0" software for several crops. The evapotranspiration in Sangasar zone was found $0.9-8 \mathrm{~mm} / \mathrm{day}$, while it was 1.5 to $12 \mathrm{~mm} /$ day in Karkuk zone. The total estimated water requirement for grape in the Soran region was found $987.6 \mathrm{~mm}$, while it was $1635.1 \mathrm{~mm}$ at Makhmur [10]. The irrigation system in pakstan is the best one in the world in spite of the water lack in the country. Therefore, from the principle of getting more crops from drop, a drip irrigation system can effecintly be used with the help of PV electricity generation and the later is the best solution for the electric availability [11].

Last but not least, Most of litreture showed an encouraging results of using PV to generate electricity for pumping system operation, which can be used for drip irrigation techniques [12, 13]. Recently, this technique has been widly used in the area where the electricity grid is not available such as rural area. The PV pumping system need to be designed carefully to get more efficient drip irrigation such as solar panels, spacing between the lateral [14]. Figure 2 summarising the parameters the affecting the PV pumping system $[15,16]$.

In Iraq, the experemintal work of using solar power system drip irrigation technique is very limited [15]. Therefore, the test, design and evaluation is very important to be studied in terms of efficiency and cost. Therefore, the current study is examined whether PV is duable to be used to operate the pumping system especially in the rural area of Iraq. Based on this, the present study was investigated a solar PV pumping system to satisfy crops water, which is needed by pressurized drip irrigation system. The related arising research questions are how the proposed system will be efficiently covered the water requirement for irrigation, the amount of water that needs to be applied and when it should be applied to a specified crop as well [9]. The present research was studied a reasonable, economic and practically applicable solutions for the electrical power shortage in addition to the lack of water required for crops irrigation in the most rural areas of Iraq (AL-Salman district). The proposed solution was conducted by modeling a solar-powered drip irrigation system using CROPWAT8.0 Software to verify the satisfaction of the recommended water needs for tomatoes crop irrigation requirement. 


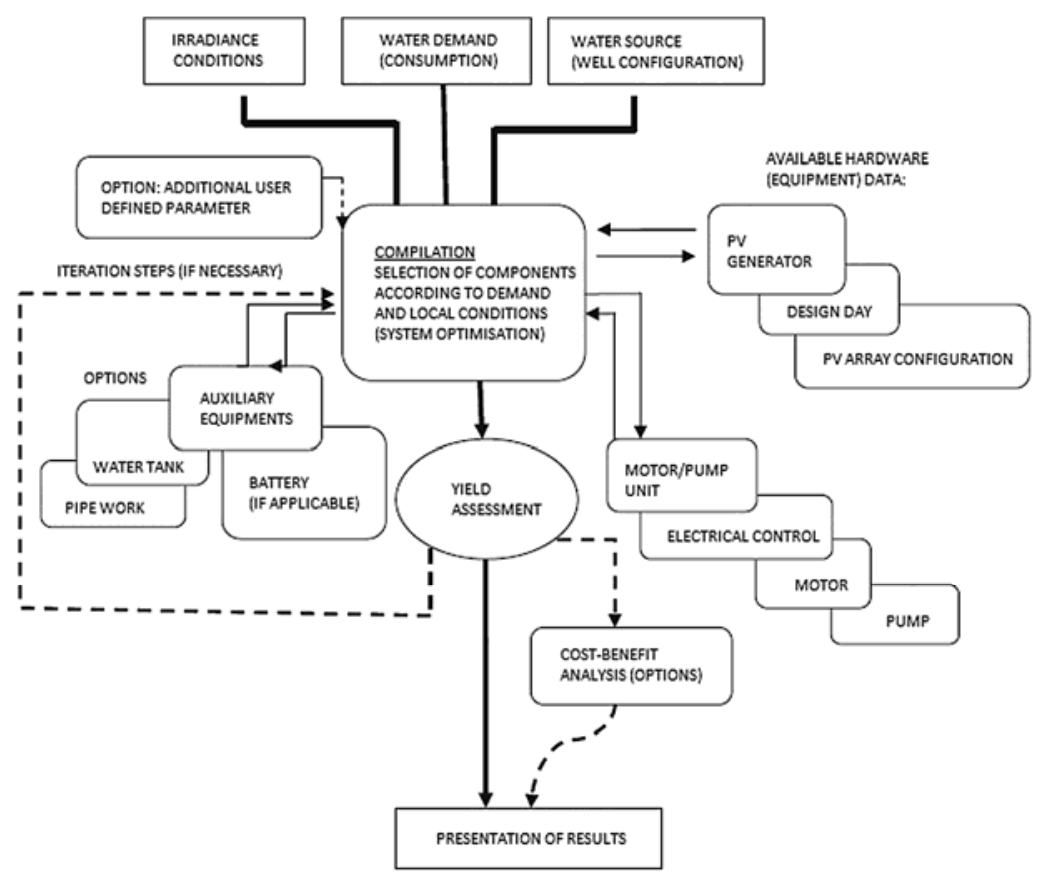

Figure 2. Factors that affected the PV water pump design [15]

\section{MATERIALS AND METHODS}

The real measured climatic data was used for estimation the crops water requirement and irrigation scheduling analysis utlizing Excel MS and CROPWAT8.0 Software. The sizing of drip network system was simulated using unique IrriPro software. The drip network system components depend on crop types, the planted area, water requirement of the plants, and soil texture. The solar pumping system was modeled by Grundfos Product Centre-based sizing software tool which is integrated in Grundfos pumping and covers solar powered systems. The proposed hardware component of the system include Solar modules, 3-Phase solar inverter, Solar Power Submersible Pump, Water Source Level Switches, electronic irrigation management and pressurized drip irrigation system as shown in Figure 3.
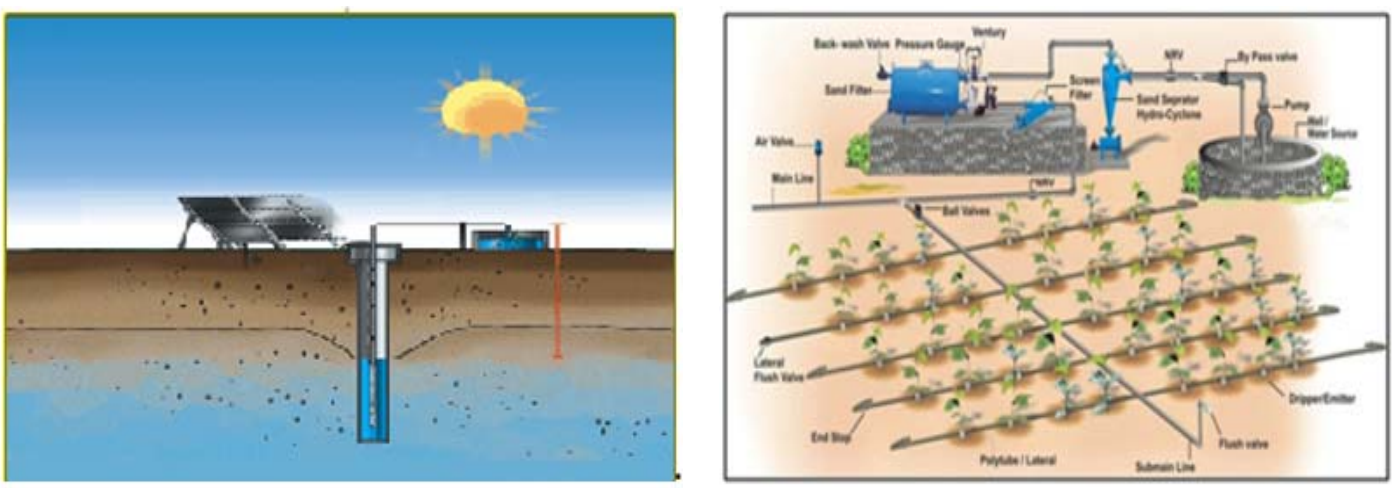

Figure 3. Layout of the solar Photovoltaic pressurized drip irrigation pumping system

\section{THE STUDIED SITE}

A solar photovoltaic pressurized drip irrigation pumping system was proposed to be installed at rural village (Abu Ghuwair) within geographical coordinate (Latitude $\mathrm{N}^{\circ} 30.5404$, Longitude $\mathrm{E}^{\circ} 45.5730$ ) in Al- Salman district/Al- Semawa governorate. The climatic data used here were collected from Al-Salman 
Agro-meteorological weather station (Latitude $\mathrm{N}^{\circ} 30.52$, Longitude $\mathrm{E}^{\circ} 44.55$ )/ministry of agriculture in Iraq as in Figure 4. The average monthly data was measured for a period (2013-2017) as in the Table 1. The proposed agricultural land is one Hectare which planted with seasonal Tomatoes crop (100\% of total land).

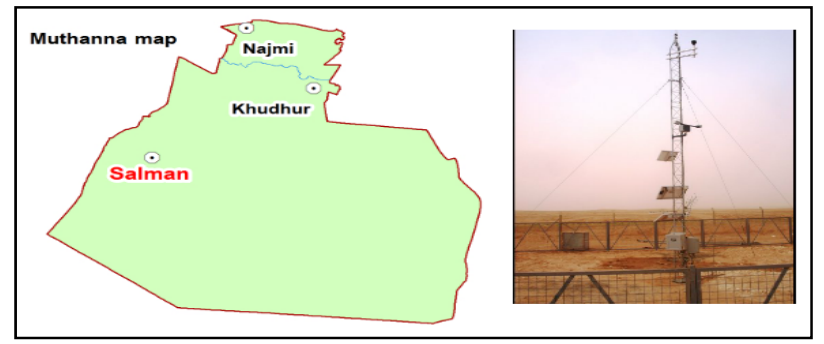

Figure 4.The location of Al-Salman Agro-meteorological weather station

Table 1. Data of Agro-meteorological for Al-Salman station

\begin{tabular}{|c|c|c|c|c|c|c|c|}
\hline Month & $\begin{array}{c}\mathrm{R} \\
\mathrm{mm}\end{array}$ & $\begin{array}{l}\text { TM } \\
\mathrm{C}^{\circ}\end{array}$ & $\begin{array}{l}\mathrm{Tm} \\
\mathrm{C}^{\circ}\end{array}$ & $\begin{array}{c}\text { Hav. } \\
\%\end{array}$ & $\begin{array}{c}\mathrm{WS} \\
(\mathrm{m} / \mathrm{s})\end{array}$ & $\begin{array}{c}\mathrm{SR} \\
\mathrm{kWh} / \mathrm{m}^{2} / \mathrm{m}\end{array}$ & $\begin{array}{c}\text { ET。_aveg } \\
\mathrm{mm} / \text { day }\end{array}$ \\
\hline Jan & 8.5 & 26.32 & 0.30 & 60.12 & 3.20 & 3.64 & 2.70 \\
\hline Feb & 7.6 & 26.56 & -0.60 & 50.48 & 3.50 & 4.79 & 3.99 \\
\hline Mar & 8.0 & 32.66 & 5.96 & 48.21 & 3.77 & 5.31 & 5.73 \\
\hline Apr & 6.0 & 39.94 & 7.09 & 37.83 & 3.87 & 6.20 & 8.11 \\
\hline May & 0.5 & 43.82 & 18.40 & 33.26 & 4.12 & 6.82 & 9.72 \\
\hline Jun & 0.0 & 45.78 & 20.42 & 16.00 & 4.44 & 7.58 & 11.79 \\
\hline Jul & 0.0 & 49.46 & 23.71 & 14.60 & 4.79 & 7.68 & 13.13 \\
\hline Aug & 0.0 & 48.60 & 23.49 & 15.95 & 3.63 & 7.35 & 10.82 \\
\hline Sep & 0.0 & 46.15 & 19.51 & 18.48 & 3.24 & 6.35 & 8.53 \\
\hline Oct & 8.3 & 40.73 & 13.43 & 33.76 & 3.16 & 4.95 & 5.67 \\
\hline Nov & 18.4 & 32.41 & 5.21 & 49.17 & 2.96 & 3.75 & 3.59 \\
\hline Dec & 4.8 & 27.47 & 0.73 & 54.73 & 3.10 & 3.37 & 2.74 \\
\hline Average & 5.2 & 38.32 & 11.47 & 36.05 & 3.65 & 5.65 & 7.21 \\
\hline
\end{tabular}

Where: $\mathrm{R}=$ Rain, $\mathrm{TM}=$ Temperature, $\mathrm{Tm}=$ Min Temperature, Hav. = humidity, WS = Avg. Wind Speed, $\mathrm{SR}=$ Total Solar Radiation, $\mathrm{ET}_{\text {。__avg }}=$ Avg Evapotranspiration.

\section{RESULTS AND DISCUSSION}

This section is devided in subsections started from the solar panel design and it's affecting parameters such as radation, sun hours, pumping system selection and invertor etc.

\subsection{Design of the solar drip water pumping system}

There are many factors was considered while designing a solar pumping system in order to select a pump, controller, sensors, solar array, wiring, and piping for the solar pumping system. These parameters can be described briefly below.

\subsubsection{Solar radiation distribution}

The distribution of solar radiation on AL-Salman is shown in Figure 5. The distribution of solar radiation was found more than $5.0 \mathrm{kWh} / \mathrm{m}^{2} /$ month from March to September with a maximum value at June and July in all the years of recording data (from 2013-2017). The minimum average values of monthly solar radiation was at December where the sun be at lowest point across the sky [17]. 


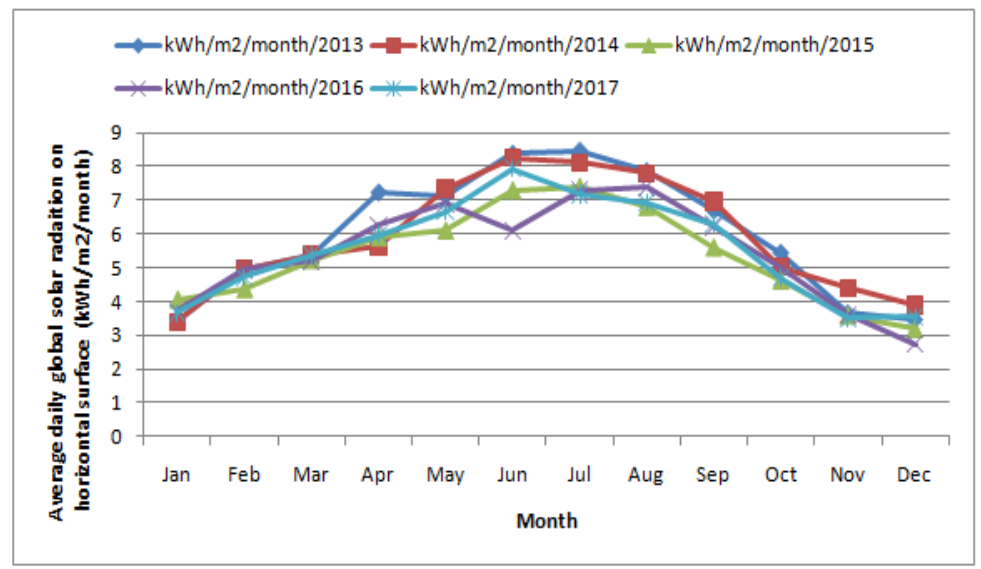

Figure 5. Solar radiation on horizontal surface of selected site

\subsubsection{Peak sun hours (PSH)}

The peak sun hours (PSH) is the average daily of sun hours that received on a surface per day, which is equivalent to the number of hours that the solar irradiance with a peak value of $1 \mathrm{~kW} / \mathrm{m}^{2}$. PSH calculation is very important in PV design which can be determined according to equation 1.

$$
\text { Peak Sun Hours (hours) }=\frac{\text { Avg.Daily Irradiation }\left(\mathrm{kWh} / \mathrm{m}^{2} \text { day }\right)}{\text { day Peak Sun }\left(1 \mathrm{~kW} / \mathrm{m}^{2}\right)}
$$

The average of PSH for the studied site was investigated for eight months from March to October, the resuts showed that more than 6 hours/day and 5.2 hours/day during four months (January, February, November and December) per a year as shown in Figure 6. It is important to investigate the capability of operation hours of solar pumping system. The global solar radiation on tilted surfaces is more than on horizontal surfaces due to increasing in reflected radiation from ground surface and objects near to the solar modules [18]

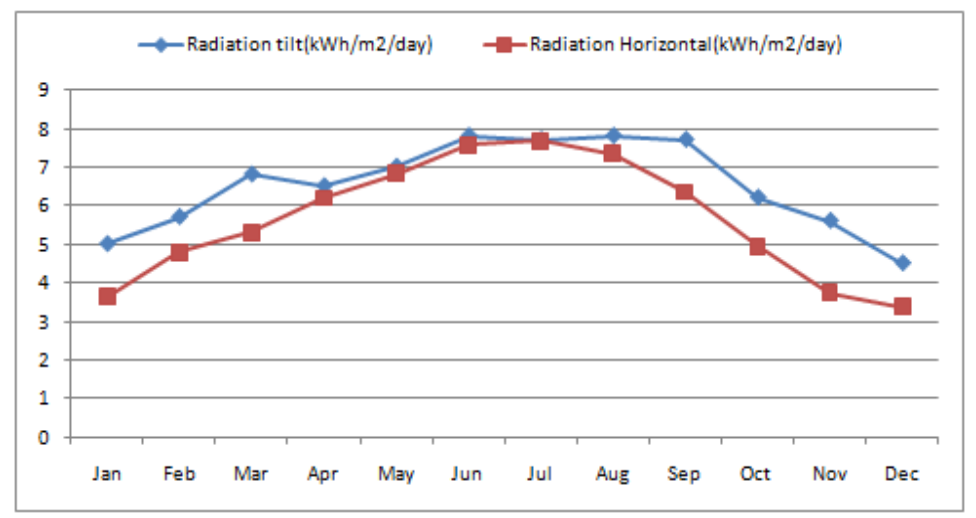

Figure 6. Average daily Global Solar radiation on horizontal and tilt surface in Al-Salman site

\subsubsection{Selection of solar water pump}

The optimum selection of Grundfos type SP 77-4 solar pump was conducted based on Head-Flow rate performance curve (H-Q) that depends on manufacturer's specifications as shown in Table 2 and Figure 7. Total dynamic head of the pump system is significant in selecting the effecint pump which can be calculated from (2).

Int J Pow Elec \& Dri Syst, Vol. 10, No. 3, Sep 2019 : 1628 - 1637 
Total Dynamic Head $(\mathrm{ft})=$ Static Head + Head losses + Friction Loss Due to Fittings

Table 2. Technical of specification solar water pump system

\begin{tabular}{cccccccc}
\hline $\begin{array}{c}\text { Type of } \\
\text { pump }\end{array}$ & $\begin{array}{c}\text { Rated } \\
\text { Voltage (v) }\end{array}$ & $\begin{array}{c}\text { Rated } \\
\text { Current(A) }\end{array}$ & $\begin{array}{c}\text { Power } \\
(\mathrm{hp})\end{array}$ & $\begin{array}{c}\text { Flow rate } \\
(\text { Liter/s) }\end{array}$ & $\begin{array}{c}\text { TDH } \\
(\mathrm{m})\end{array}$ & $\begin{array}{c}\text { Pumping } \\
\text { level (m) }\end{array}$ & $\begin{array}{c}\text { Power } \\
\text { factor }\end{array}$ \\
\hline centrifugal & 380 & 34.5 & 22.54 & 21.416 & 48.84 & 38 & 0.82 \\
\hline
\end{tabular}

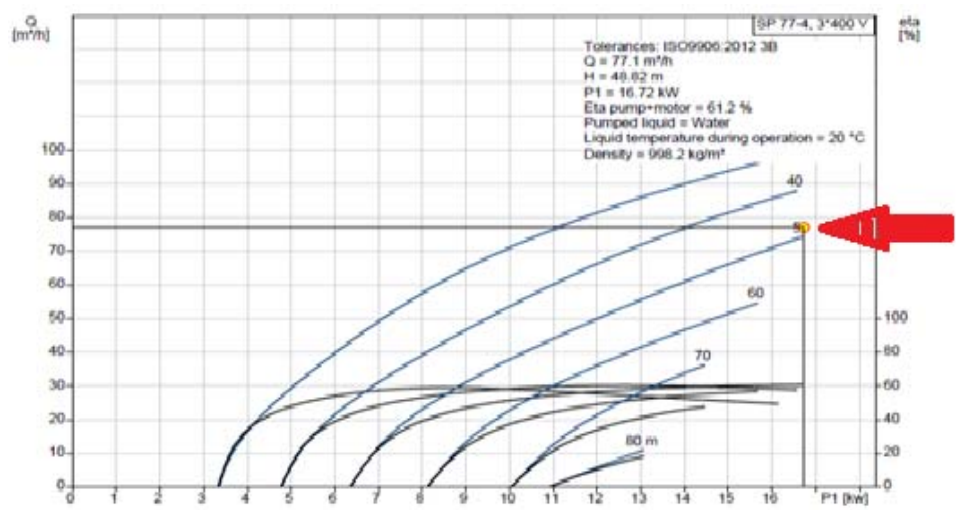

Figure 7. Performance curve of selected SP 77-4 solar pump

\subsubsection{Solar inverter}

RSIIP66 is the off-grid solar inverter model with the built-in MPPT, it supplied with a various protection software whcih is compatible with SP submersible pumps. The inverter is compound with a sinewave filter that have a high quality, which converts the output pulses of the frequency into sine-wave-shaped and resulting a pure sine-wave-shaped current which reduced motor noise [19]. Polycrystalline 270W photovoltaic panel was selected for this system. The peak value voltage and current for this panel are $31.6 \mathrm{~V}$ and 8.76 A respectively [20]. The peak power of the solar photovoltaic system was $17.82 \mathrm{~kW}$, it consists of 66 modules connected in 13 panels per string with 5 columns in parallel. The technical specification of the adopted GRUNDFOS (GF 270) solar modules is shown in Table 4.

Table 4. Electrical characteristic for solar inverter

\begin{tabular}{ccccc}
\hline $\begin{array}{c}\text { Maximum power } \\
\text { point voltage }(\mathrm{V})\end{array}$ & $\begin{array}{c}\text { Open circuit } \\
\text { voltage }(\mathrm{v})\end{array}$ & $\begin{array}{c}\text { Max power } \\
\text { point current(A) }\end{array}$ & $\begin{array}{c}\text { Module shortcut } \\
\text { current(A) }\end{array}$ & $\begin{array}{c}\text { Maximum power } \\
\text { output(W) }\end{array}$ \\
\hline 31.6 & 38.4 & 8.76 & 9.11 & 270 \\
\hline
\end{tabular}

\subsubsection{Sizing results of solar pumping system water production}

The quantities of water production from the solar pumping system is presented in Table 5.

Table 5. Water production from solar pumping system

\begin{tabular}{ccc}
\hline $\begin{array}{c}\text { Total water production } \\
\text { per year }\left(\mathrm{m}^{3}\right)\end{array}$ & $\begin{array}{c}\text { Avg. water production } \\
\text { per day }\left(\mathrm{m}^{3} / \text { day }\right)\end{array}$ & $\begin{array}{c}\text { Average water production } \\
\text { per watt per day }(\mathrm{Wp} / \text { day })\end{array}$ \\
\hline 230000 & 629.3 & 21.61 \\
\hline
\end{tabular}

\subsection{Design of pressurized drip irrigation system}

The pressurized drip irrigation system was simulated by using a unique IrriPro software. The optimum operating pressure and discharges of the emitters were set to insure that the absorption rate of soil water by plants without water stress. The layout of the drip irrigation system is shown in Figure 8 . The quantity of the emitters was calculated of 32225 according to the planting area (plan of tomatoes). The space between two consecutive emitters is $40 \mathrm{~cm}$, and the distance between one rows to the next is 75 $\mathrm{cm}$ with single lateral for each row of plants. The analysis showed that the uniformity coefficient (WU) value were found more than of $90 \%$, and the flow rate was in an acceptable range of $(0.2-7.0) \mathrm{m} / \mathrm{s}$ and the possible 
variation of the network falls inside the acceptable pressure limits of Paverage $\pm 10 \%$. The designed system here was achieved a high value of uniformity which commensurated with the needs and the sensitivity of the adopted tomatoes crop to the variations of water delivery. The total number of Lateral are 131 with a diameter of each ones is $14 \mathrm{~mm}$ and $98.65 \mathrm{~m}$ length.The internal diameters of the selected main and secondary, sub-main and lateral pipes were $110.2 \mathrm{~mm}, 79.2 \mathrm{~mm}$ and $14 \mathrm{~mm}$ respectively [21].

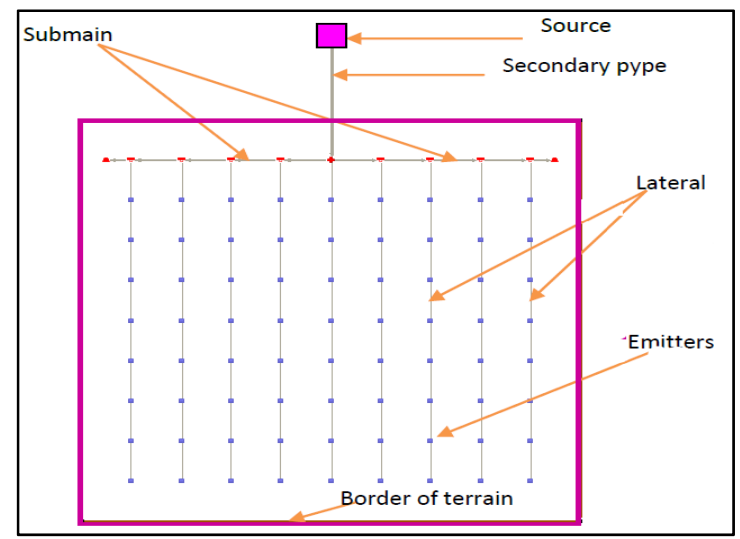

Figure 8. The layout of the drip irrigation system of a single classic square sector in (100 m length)

\subsection{Results of water requirements}

The output of CROPWAT 8.0 modeling of climate data (temperatures, wind speeds, humidity, sun hours and solar radiation) in addition to evapotranspiration and rain chart is shown in Figure 9. The evapotranspiration increases with the increasing of temperatures and solar radiation, while the humidity decreasing to its minimum values at summer months which indicates more water should be supplied to compensate the lost soil moisture. Whenever there is a rainfall, the evapotranspiration will be decreased accordingly as clearly indicated in Figure 9.

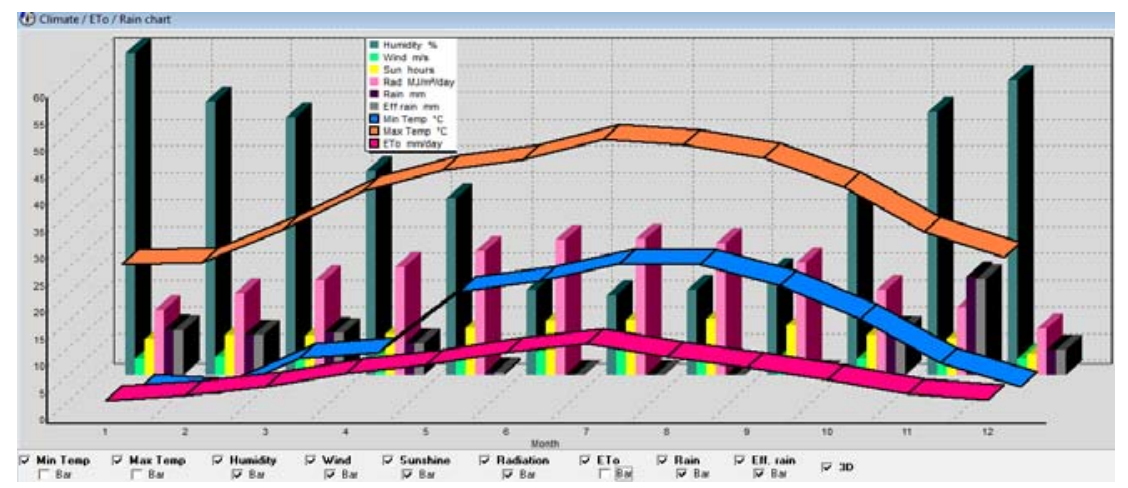

Figure 9. Climate data at Al-Salman District

(temperatures, wind speeds, humidity, sun hours and solar radiation)

The tomatoes water requirement graph is indicated in Figure 10, the figure clearly showed that the crop evapotranspiration (ETc) increases from initial planting stage and mid-season stages to a maximum values. This is due to the increase of the uptake water by plant to avoid water stress which have a negative impact yields. Tomatoes crop is most sensitive to water deficit, during development, flowering and yield or harvest stages [20].

Int J Pow Elec \& Dri Syst, Vol. 10, No. 3, Sep 2019 : 1628 - 1637 


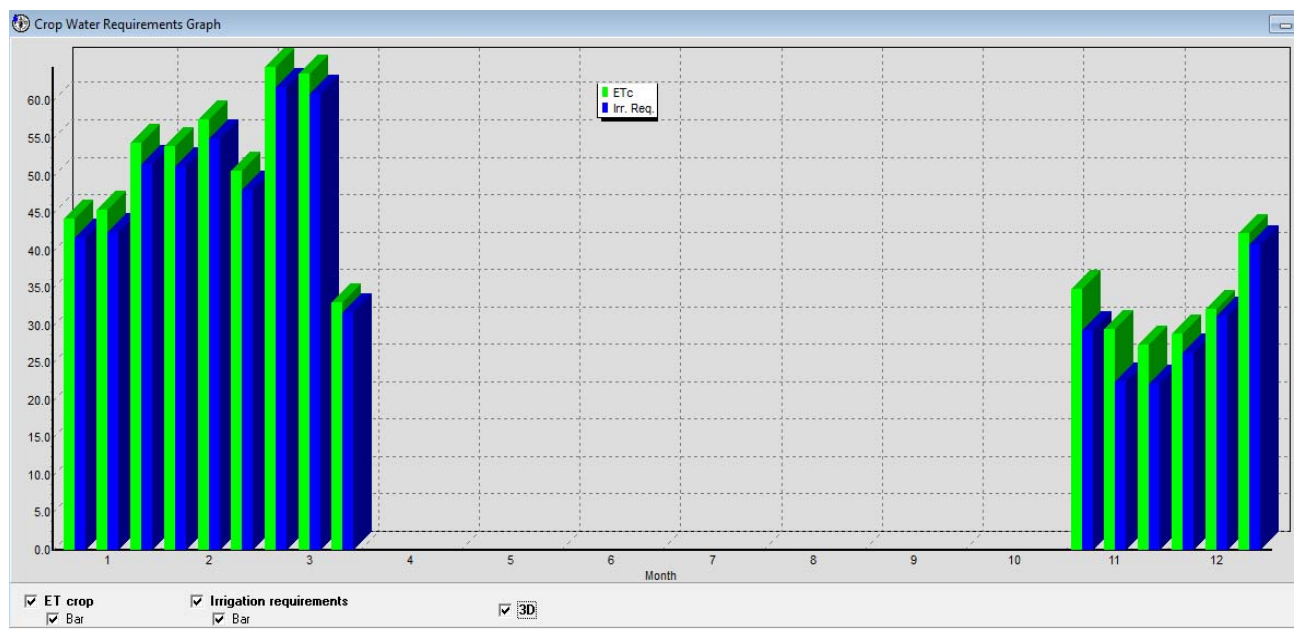

Figure 10. Graph of tomatoes water requirement

The amount of water that can be stored in root zone during growing stages of the plant is representing the net irrigation (NIR) as indicated in Figure 11. The gross irrigation depth (GIR) of required water is more than the (NIR) in losses of water due to evaporation, leakage, percolation, etc. The ratio of GIR to NIR is the irrigation efficiency of drip and the irrigation system (Ea) was found of $92 \%$. The gross and net requirement of water is increased from planting stage till the end of harvesting stage throughout of tomatoes period life growing. The total accumulated required water depth was found $636.4 \mathrm{~mm}$ and $707 \mathrm{~mm}$ for NIR and GIR respectively [21].

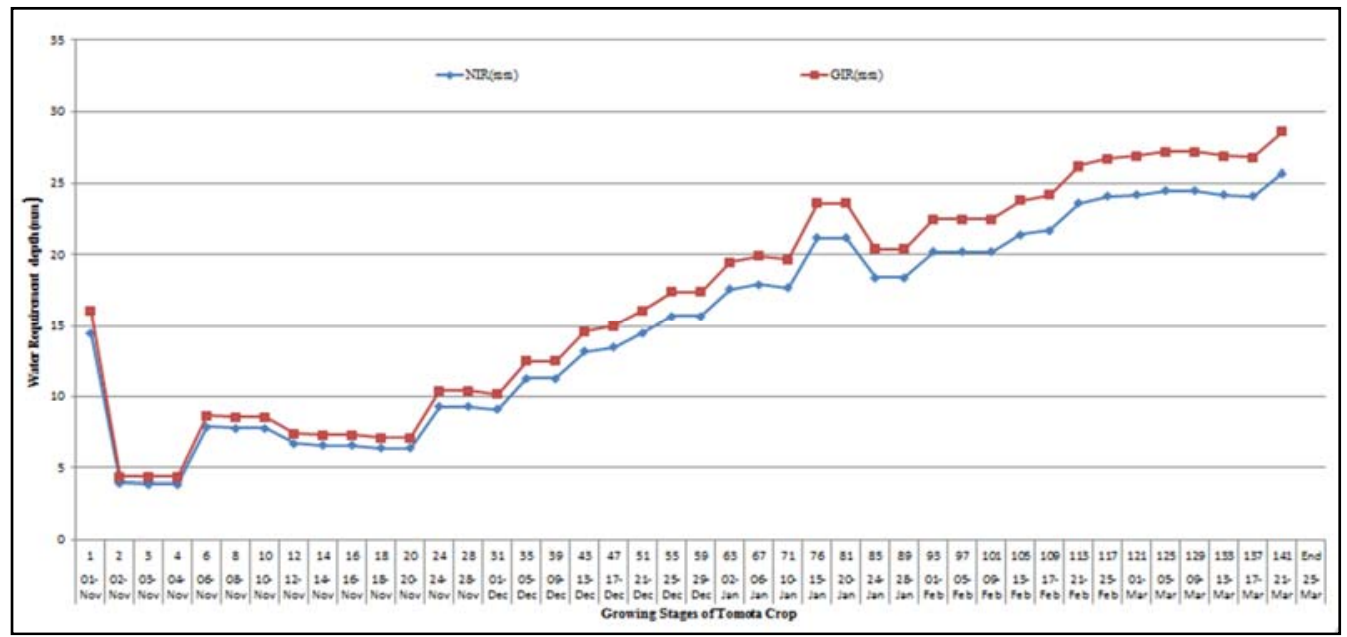

Figure 11. Graph of total net and gross water requirement of tomatoes crop

The irrigation time scheduling was also computed. The interval between successive irrigation practices is one day during the beginning of the initial stage, then changed to two days at the rest period of the stage during November. Through the development stage, the interval is ranging between 4 and 5 days during December and first decade of January. The intervals between practices at mid-season (from flowering till to start of maturity stage) was four days, which starting from second decade of January to the end of the second decade of February. At late season stage (starting from maturity to harvest or full senescence stage), the interval was also found of four days during March. Therefore, the majority of water consumption was found during the flowering and maturity intervals.

\subsection{Monthly productivity of solar water pumping}


The monthly productivity of water pumping from the well to drip irrigation system for watering the tomatoes crop is shown in Figure 12. The maximum water production is $695.6 \mathrm{~m}^{3} /$ day at June, while the minimum value is $529.1 \mathrm{~m}^{3} /$ day at December with an annual water production of $399 \mathrm{~m}^{3} /$ day. The figure clearly showed that the maximum daily water production is occured at June where maximum water demands through the driest months in summer season. However, the monthly water production is exceeding the crop water requirement which indicates that the solar pumping system is technically feasible to install with drip irrigation system. The total water production is $230000 \mathrm{~m}^{3} /$ per year which indicates compatible overall system design and adequate to irrigate more planting land with same or other crop types.
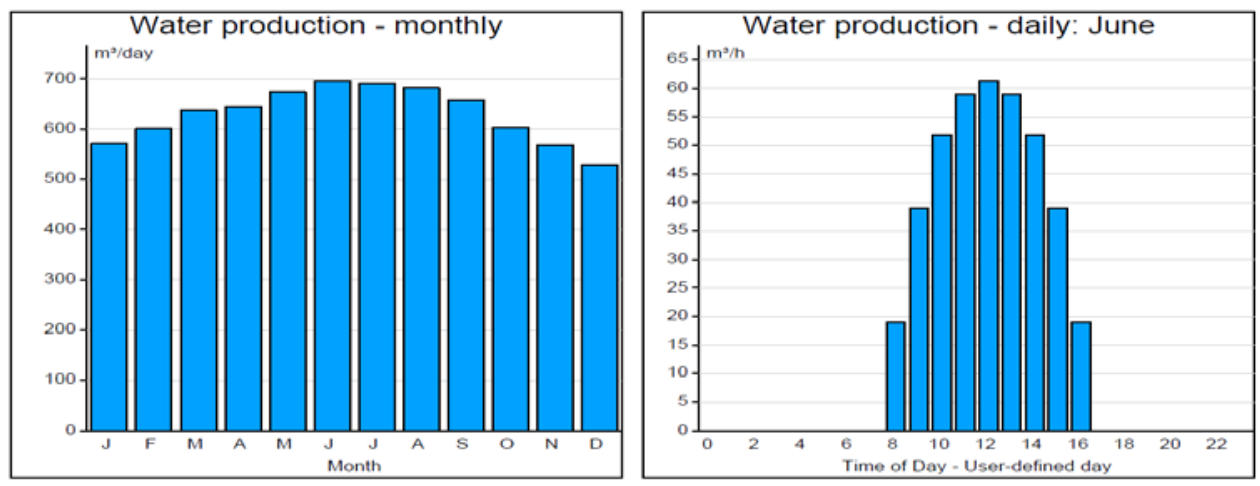

Figure 12. Daily and monthly water production

\section{CONCLUSION}

The outcome of this study was an attractive encouragement for adopting solar PV pumping system with using drip irrigation technology. Unique software tool was used in design of drip network system that performed a rigorous calculation in determining the pressure, flow rate, speed, to which each element is subjected, and consequently the plant behavior. The calculations were considered the hydraulic and geometric characteristics of each element, arrangement and slope, local losses and load speed with a uniformity coefficient (WU) value more than $90 \%$, which insure the acceptable pressure variation and the velocity of water flow rate in the piping network system. Then, the solar pumping sizing based on H-Q performance curve was calculated to insure that the system is operated at maximum flow rate of $64.45 \mathrm{~m}^{3} / \mathrm{h}$ at pump capacity of $16.79 \mathrm{~kW}$ with compounds motor pump efficiency of $61.2 \%$. This led to a total water production of $230000 \mathrm{~m}^{3} /$ per year, which indicates compatible overall system design and adequate to irrigate more planting land with same or other crop types. Finally, this study has some really useful guidelines on the solar drip irrigation pumping system design can be driven from this research.

\section{REFERENCES}

[1] Itimad D. J. Azzawi, Samir Gh Yahya, Layth Abed Hasnawi AL-Rubaye, "The Feasibility of Using Off-Grid Hybrid System for the City of Diyala Iraq," International Journal of Mechanical Engineering and Technology, 9(10), pp. 1258-1267, 2018.

[2] DihrabSalwan S., Kamaruzzaman Sopian, "Electricity generation of hybrid PV/wind systems in Iraq," Renewable Energy, 35(6) 1303-1307, 2010.

[3] Layth Abed Hasnawi Al-Rubaye, Itimad D. J. Azzawi, Saadoon Abdul Hafedh, "Building Hybrid Energy System, PV/Wind Turbine using Local Material," Journal of Engineering and Applied Sciences, 14(3), pp. 870-878, 2019.

[4] E. O. B. T. Sabah Miqoi, "Adaptive fuzzy sliding mode based MPPT controller for a photovoltaic water pumping system," International Journal of Power Electronics and Drive System (IJPEDS), Vol. 10, No. 1, 2019.

[5] Kumar, M, reddy, K.S, adake, R.V, Rao, C.V.K.N, "Solar powered micro-irrigation system for small holders of dryland agriculture in India," Agricultural Water Management, Amsterdam, v.158, p.112-119, 2015.

[6] Shoeb, M.A, Shafiullah, G.M., "Renewable Energy Integrated Islanded Microgrid for Sustainable Irrigation-A, Bangladesh Perspective," Energies, 11, 1283, 2018.

[7] Ebaid, M.S.Y, Qandil, H., Hammad, M., "A unified approach for designing a photovoltaic solar system for the underground water pumping well-34 at Disi aquifer," Energy Convers. Manag., 75, 780-795, 2013.

[8] Narale, P.D, Rathore, N.S, Kothari, S., "Study of solar PV water pumping system for irrigation of horticulture crops," International Journal of Engineering Science Invention, v. 12, n. 12, p. 54-60, 2013. 
[9] Deveci O, Onkol M, Unver HO, Ozturk Z., "Design and development of a low-cost solar powered drip irrigation system using Systems Modeling Language," J Clean Prod, 102:529-44, 2015.

[10] Persad P, Sangster N, Edward C, Ramkhalawan A, Maharajh A., "Investigating the Feasibility of Solar Powered Irrigation for Food Crop Production: A Caroni Case," J. Assoc. Profess. Eng. Trinidad Tobago, 40(2):61-65, 2011

[11] Anonymous, Pakistan Statistical Yearbook. Federal Bureau of Statistics, Statistics Division, Ministry of economic affairs and statistics, Govt. of Pakistan, Islamabad, Pakistan, 2008.

[12] Aligah MA., "Design of Photovoltaic Water Pumping System and Compare it with Diesel Powered Pump," Jordan J. Mech. Ind. Eng., 5(3):273-280, 2011.

[13] Kelley LC, Gilbertson E, Sheikh A, Eppinger SD, Dubowsky S., "On the feasibility of solar-powered irrigation," Renewable and Sustainable Ener. Rev. 14:2669-2682, 2010.

[14] Purohit, P, A. Michaelowa., "CDM potential of SPV pumps in India," Renewable and Sustainable Energy Reviews, 12:181-199, 2008

[15] Wazed, S.M, Hughes, B.R, O’Connor, D. and Calautit, J.K., "A review of sustainable solar irrigation systems for Sub-Saharan Africa," Renewable and sustainable Energy Reviews, 81(P1), pp.1206-1225.

[16] Bucher W., "Aspects of solar water pumping in remote regions," Energy Sustain Dev, 3:8-27, 1996.

[17] A. K. A. T. S. Zaid Hussein Ali, "Modeling Solar Modules Performance Under Temperature and Solar Radiation of Wastern of Iraq," International Journal of Power Electronics and Drive System (IJPEDS), vol. 9, no. 4, pp. 1842-1850, December 2018.

[18] Purwahyudi, Bambang; Kuspijani, Kuspijani; Ahmadi, Ahmadi, "SCNN Based Electrical Characteristics of Solar Photovoltaic Cell Model," International Journal of Electrical and Computer Engineering (IJECE), vol. 7, no. 6, pp. 3198-3206, 2017.

[19] Kia, Dawod Rasooli, "Water requirements for major crops in different agro-climatic zones of Iraqi Kurdistan using by CROPWAT 8.0." IOSR Journal of Agriculture and Veterinary Science (IOSR-JAVS), 6.3: 30-36, 2013.

[20] Saifuddin M. Jalil, Faizar Abdurrahman, Selamat Meliala, Rosdiana, "Design of Maximum Power Point Tracking for Solar Collector Drying System: An Experimental Study," International Journal of Power Electronics and Drive System (IJPEDS), vol. 9, no. 4, pp. 1799-1803, 2018.

[21] Campana, Pietro Elia, Li, Hailong, Yan, Jinyue, "Dynamic modelling of a PV pumping system with special consideration on water demand," Applied Energy, 112: 635-645, 2013.

\section{BIOGRAPHIES OF AUTHORS}

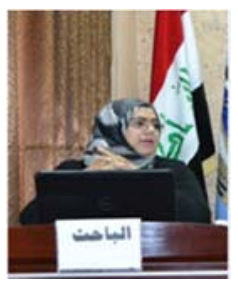

Raghad A. ALjourni received his B.Sc from University of Technology Baghdad in Iraq in 1993, MSc from University of Technology Baghdad at 2005, PHD from South Russian State Technical University in Russia in 2015 work at college of engineering University of Diyala Iraq.

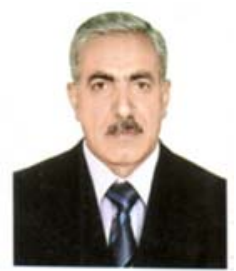

Samah Shyaa Oudah received his B.Sc from University of Baghdad in Iraq in 1986, MSc from Iraqi Institute for Higher Studies at 2014. Working a Lecturer and scientific researcher in the field of solar and wind energy in different nongovernment orginizations and private instituties that holding training courses in the field of both solar and wind energy training practice and courses.

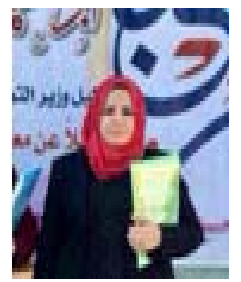

Rasha Yasen Abed received his B.Sc from college of engineering University of Diyala in Iraq 2002, MSc from University of Technology Baghdad at 2015, work at college of engineering University of Diyala Iraq. 